\title{
ANALISIS FAKTOR - FAKTOR TRANSMISI LOKAL COVID-19 DI PRAKTEK DOKTER GIGI
}

\author{
Astri Yosika Olivia M.P $P^{1}$, Suci Erawati ${ }^{2}$, Mangatas Halomoan Parluhutan Hutagalung ${ }^{3}$ \\ Fakultas Kedokteran Gigi Universitas Prima Indonesia ${ }^{l}$ \\ e-mail : ${ }^{1}$ astriyosika98@gmail.com, ${ }^{2}$ esuci64@gmail.com, ${ }^{3}$ mangatashutagalung@yahoo.com
}

\begin{abstract}
The city of Wuhan is the city where the COVID-19 virus has been detected for the first time. This virus originates from the subfamily Orthocoronavirinae and has four genera, namely: ( $\beta$-COV) $\beta$-coronavirus, $(\alpha-c o v) \alpha$ coronavirus , $(\delta$-COV) $\delta$-coronavirus, and $(\gamma-C O V)$ coronavirus (Li et al., 2020). Transmission in a dentist's practice is very likely due to inhalation of Aerosols or droplets containing viruses. To prevent transmission in the dentist's practice, actions such as a dental doctor using PPE level 3, hand sanitizers are placed in each room to wait, Patients who come are required to wear a mask and check body temperature. The aim of the literature study on COVID-19 ini to find out about the outbreak and prevention of COVID-19 at the Dentist's Office. The conclusion of the literature study is that the cause of COVID-19 is SARS-COV2 which shows that the RNA virus has a sample (sheath) and is also a species of the genus $\beta$-COV2. This virus has a diameter varies between 60-140 nm. The entry of the virus into the host body pitch hanging to the ability of ACE2 binds to the virus, wherein the receptor from the membrane extracellular expressed in epithelial cells.

Keywords : Corona Virus, SARS-COVID-2, Dentist's Practice.
\end{abstract}

\begin{abstract}
ABSTRAK
Kota Wuhan merupakan kota yang pertama sekali terdeteksi adanya virus COVID-19. Virus ini berasal dari subfamily Orthocoronavirinae dan memiliki empat genus yaitu: $(\beta$-COV) $\beta$-coronavirus, $(\alpha$-cov $) \alpha$-coronavirus ,$(\delta$-COV) $\delta$-coronavirus ,dan $(\gamma-\mathrm{COV}) \gamma$ coronavirus (Li et al., 2020). Penularan di Praktek Dokter Gigi sangat mungkin terjadi akibat terhirupnya Aerosol atau Droplet yang mengandung virus. Untuk mencegah terjadinya penularan di praktek dokter gigi dilakukan tindakan seperti dokter gigi menggunakan APD level 3, hand sanitizer diletakkan disetiap ruangan untuk tunggu, Pasien yang datang diwajibkan menggunakan maskernya serta mengecek suhu tubuh. Tujuan dari studi literatur mengenai COVID-19 ini untuk mengetahui penjangkitan serta pencegahan COVID-19 di Praktek Dokter Gigi. Kesimpulan studi literatur yaitu penyebab COVID-19 adalah SARS-COV2 yang menunjukkan virus RNA memiliki sample (selubung) dan juga merupakan spesies dari genus $\beta$-COV. virus ini memiliki diameter bervariasi antara 60-140 nm. Masuknya virus ke dalam tubuh inang tergantung kepada kemampuan ACE2 berikatan dengan virus, dimana reseptor dari membran ekstra selular diekspresikan di sel epitel.
\end{abstract}

Kata Kunci: Corona Virus, SARS-COVID-2, Praktek Dokter Gigi.

\section{INTRODUCTION Background}

In 2019, in December, the world was shaken by a staggering number of serious infections of unknown cause. The World Health Organization (WHO) received a report at the end of 2019 from China that it was found in Hubei province, precisely in the city of Wuhan, China, there were 44 pneumonia sufferers. At first it was thought that there was a market that traded marine animals, river fish and various other animals. The cause of the new corona virus was successfully identified and the genetic code was obtained on January 10, 2020 (Hendayani et al., All, 2020).

Corona virus disease (COVID-19) is spreading very rapidly throughout the country. The COVID-19 outbreak was declared by WHO in 2020, in March (WHO, 2020) . The first COVID-19 pandemic in Indonesia was declared 2 Maret 2020. The number of confirmed cases was 64,958 and the number of deaths was $3,241(4.99 \%)$. 
The COVID-19 virus has a huge impact on various medical industries, including dentists, because it is very easy to contract various diseases that can be transmitted and are exposed to saliva and blood (Laheij et al., 2020).

\section{In dentist practice, COVID -19 can spread very quickly, caused by droplets, aerosol droplets carrying viruses and virus-contaminated mucous membranes, oral fluids and surface devices (Chen et al., 2020).}

during the plague COVID-19, there are six doctors died from 24 number of doctors, reported by the IDI (Indonesian Doctors Association). Meanwhile, according to data from the Indonesian National Nurses Association (PPNI) per May 8th, 2020 , the number of cases ehatan (P nurses) exposed COVID-19 expanded. The number of ODP (People Under Supervision) is around 596, while the OTG (People Without Symptoms) is estimated to be 97 people, of whom 19 people have died and who tested positive for 53 people besides that for PDP (Patients Under Supervision) as many as 48

people.

The Ministry of Health (KEMENKES) and Disaster Management Agency (BN P B ) appeal to all dentists to temporarily stop their services because they are very likely to be infected with COVID-19, but for emergencies it is still handled. It is estimated that the dentist has not practiced the drug for 4 months for COVID- 19.

PB-PDGI is in line to apply the "New Normal Life" so that all dentists in Indonesia can return to practice according to health protocols. Regulations are designed to support dentists or health workers to avoid COVID-19 .

\section{Problem Formulation}

How to analyze local transmission of COVID-19 in a dentist's office.

\section{General Purpose}

Knowing the cause of the local transmission of COVID-19 that occurs in the practice of dentists

\section{Special Purpose}

1. This is to determine the analysis of local transmission factors for COVID-19 in a dentist's practice.

2. To prevent the occurrence of local transmission factors in dentist practice.

\section{LITERATURE REVIEW}

\section{History of Covid and Its Spread}

On December 1, 2019, P rovincial Hubei, China precision in wuhan city beginning COVID19 was detected while Indonesia was detected beginning March 2, 2020 when two people confirmed infected with transmission by someone from Japan.

Using the 2019-nCOV genome isolated from infected patients in Wuhan, a study was carried out to determine the pathogen causing the outbreak in Wuhan. Corona virus is an RNA virus that has a particle size of 60-140 nm ( Meng et all., 2020)

At the end of January, in 2020 this direct human-to-human transmission soared up to 2000 cases of contracting COVID-19 in one day. Corona virus was unveiled WHO became the name of the outbreak extends across the surface of the earth, on February 11th, 2020 (Handy et al 1 ., 2020)

The public is increasingly panicked because the number of infected sufferers continues to increase and spread outside China, including in Indonesia. There are around 200 countries most affected by the virus, namely the United States with around 186,046 people positive for the corona virus, followed by Italy (105,792 cases) and Spain ( 95.923 cases). In Indonesia , 3,512 positive cases occurred on April 10, 2020, 282 cases recovered, and 306 people died. The number of cases the death rate is 9.1\% (Ministry of Health RI; 2020) .

When various cases prove pandemic $d$ itularkan from person to person, doctors and medical personnel dealing with patients who were treated without a history of going to the market that has been closed, resulting pandemic threat increases (Handy et al., 2020).

The corona virus is a new epidemic that is spreading rapidly and no cure has been found, a lot of information cannot be obtained through social media, and not everyone can trust this information, and it creates a stigma for people related to COVID19.

As a new disease that is spreading rapidly, there is no cure, and a lot of information cannot be obtained through social media, and not everyone can trust the information, which embarrasses those associated with COVID-19. Therefore, the review aims to provide 
information. Be rdasarkan development diagnosis and treatment . (Zhu et all., 2020 ).

the initial signs of COVID-19 are unclear, fever occurs ,

coughs heal spontaneously or become short of breath, and inflammation of the lungs that causes acute respiratory distress syndrome (ARDS), blood clotting disorders, decreased kidney function, decreased organ function (Chen et al. , all ., 2020).

Corona viruses are zoonotic in nature which can be transmitted from animals to humans but some evidence has been found that transmission between humans through droplets.

Various kinds of transmission of infection in the doctor's practice, such as saliva, hands, respiratory secretions, particles or dust used for burial, blood splashes, clothes and hair as well as dental tools and other equipment.

\section{Social Impact of Covid}

As a result, there has been an increase in reports of people who are positive for Covid-19, especially those from areas affected by the outbreak. The impact appears the following community stigma encourages people not to tell the disease, to avoid discrimination, prevents people from seeking treatment when they feel symptoms, prevents people from developing healthy behaviors and leads to more serious health problems, prolonged transmission and difficulty controlling the spread of the virus outbreak. this corona.

As far as COVID-19 is concerned, a growing number of reports are showing that people in areas affected by the epidemic are being stigmatized by the public. In Indonesia, the stigma arises because social behavior, namely: isolation of survivors / patients who had recovered from Covid- 19 because it is believed to give the pen a snake 's disease, rejection and isolation of people who moved from one place to another, isolation Ras particular, for their assuming being a virus carrier, isolating medical personnel / health workers because they work in a hospital, this is believed to be able to spread the corona virus.

\section{Effects of Local Covid Transmission in Dentist Practices}

Dentists belonging to the category of professionals can be at risk of spreading the virus. The assessment is based on the possible spread of behavior known or suspected to contain the virus that causes COVID-19.
The outbreak has affected health workers, including oral and dental therapists or dentists and dental nurses . prone work with various infections due to frequent contact with saliva and blood (Laheij et al., 2012).

The virus that causes COVID-1 9, SARSCOV-2, could have spread to dental practice, due to inhalation of aerosols and droplets containing microbes and direct contact through mucous membranes, oral fluids, equipment and exposure to microbes (Chen et al. al $1 ., 2020)$.

During the COVID-19 pandemic, patient treatment and action is needed to prevent hospital infections. $\mathrm{P}$ asien to enter the clinic is limited to prevent transmission of the virus between patients (Lai et al., 2020).

The Indonesian Dental Association (PDGI) and the Association of Indonesian Dental and Dental Hospitals (ARSGMPI) have published manuals for dentists "New Normal" and "Guidelines for Practical Management of Dental and Oral Hospitals " as basic guidelines for dentists to perform dental care. .

\section{Virus Checking Process}

The checks carried out to detect the disease COVID-19, M etode RRT-PCR test swab (swab) throat, bronchoalveolar lavage is used, and a $C T$ scan of the chest is a test Diagnovision sticks for viruses corona in order to get a picture of normal to abnormal y aitu: fluid buildup, inflammation pleurisy and pneumonia other features (Guan et al 1 ., 2020).

\section{Precautions in Dentist's Practice}

The California Dental Association (CDC ) recommends using grade $3 \mathrm{PPE}$, including an N95 mask, gown, sterile gloves, safety cap, and protective shoes. When they want to take steps that can cause aerosols (Peng et all., 2020) .

The first level is the use of surgical masks, headgear, white coats, face masks or goggles and latex gloves or nitrile completely disposable to provide standards for the protection of the clinic staff. The second level is used to provide protection for doctors like a gown. At the same time, the third level is for following up on patients with suspected or diagnosed COVID19. PPE level 3 uses protective clothing ( hazmat ). If there are no items, you can use a white coat with a dress all the time, add wearing goggles or face masks, shoe covers and sterile gloves . (Peng, X et a $11 ., 2020$ ). 
Vol. 16 No. 1 Januari - April 2021

It is advisable to use hydrogen peroxide mouthwash $1 \%$ or $0.2 \%$ povidone to reduce microorganisms in saliva, including SARS- CoV2 (Ather, A et al 1., 2020).

\section{RESEARCH RESULT}

\section{VIRUS CHARACTERISTICS}

Characteristics of the SARS-COV-2 virus

Quoting from the dentist book "New Normal Era" published on July 2 020, the SARS- COV-2 virus describes a positive RNA virus that comes from the Ortho coronavirinae subfamily of the Coronavirus family (Similar to the results obtained by ZHU et al. . 2020). The orthocoronavirinae subfamily of Nidovirales has four consecutive genera, consisting of $\alpha$ - coronavirus $(\alpha$-cov $), \beta$ coronavirus $(\beta-\mathrm{COV}), \gamma$ - coronavirus $(\gamma-\mathrm{COV})$ and $\delta$-coronavirus ( $\delta$-COV) (Li et al., 2020). Among the four genera, SARS- COV-2 is a type of $\beta-C O V-2$. Microbials that can be isolated into mammals are shown in Figure 1:

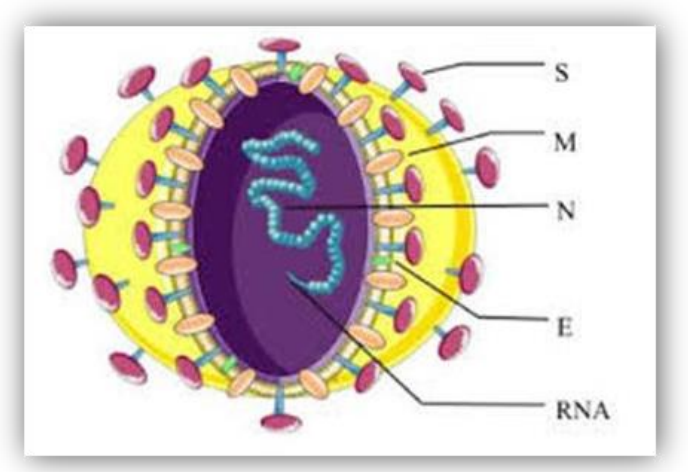

Figure 3.1 Form of the SARS-COV-2 virus

The form of microbes is made up of four proteins, namely: (S) ear, lying on the surface and listed on the top of glycoproteins; (M) protein membrane ; $(\mathrm{N})$ nucleocapsid protein; (E) Cover / cover protein. RNA is a nucleic acid present in the core of the nucleocapsid (Li et a 11., 2020); B. False color scanning electron micrograph of SARS-COV2 in human cells. the electron microb (orange) the front (blue) . (TSIA

et a $11 ., 2020$ )

However, it is slightly different from the MOHA-Covid19 guidebook which states that usually polymorphs with a diameter of 60-140 and COVID-19 belong to Flor eliptic. MERS- COV and SARS-COV are genetically very different. Current research shows that homology exists between the two, namely that the COVID-19 DNA characteristic of having the corona virus in bats / SARS exceeds $85 \%$.

Quoted from the KEMENDAGRI-PreventCovid19 book as well as the dentist's handbook below normal, there is a new suitability regarding virus spawning or transmission as below.

\section{Transmission or Transmission of Viruses}

The World Health Organization (WHO), the Center for Disease Control and Prevention and the Ministry of Health has proven that respiratory infections can spread based on particle size, namely the spread of particles $>50 \mu$ (Harrel et al., 2004). The droplets are larger than $10 \mu$ and the aerosol particles are $0.3-10 \mu$. The Center for Disease Control and Prevention (CDC), WHO also acknowledges that these three forms of transmission are the modes of transmission of the SARS-COV-2 virus (WHO, 2014). The distribution diagrams of splashes, droplets and aerosols are shown in Figure 2 as follows:

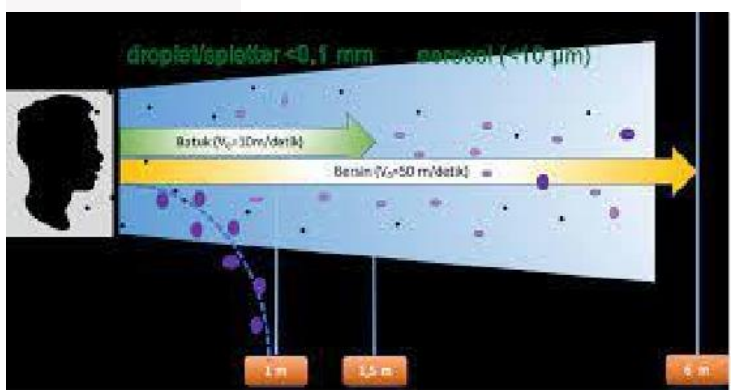

Figure 3.2 Virus Transmission Transmission

Transmission of virus transmission, Illustration of splash distance, droplets and aerosol particles (Froum and Strange, illustration modified in 2020).

A dentist guidebook in the new normal era, the results of research by Rahmi Amitha et al. (2020) is the same as the results of Ira Lia Sari's (2020) research on the SARS-COV-2 prevention literature, which shows that the method of laying the SARS-COV-2 virus includes:

\section{Spalatter}

The SARS-COV-2 virus can transmit while speaking, which secretes droplets of fluid from between humans. Splatters are ballistic in that they apply a certain amount of force from one location to another . $\mathrm{P}$ articles are very large of droplets in the air, can stay in the air for a short time, and can reach an area of less than $1 \mathrm{~m}$ (Harrel et al., 2004).

\section{Droplet}

The droplets can be referred to as melted droplets. The water droplets move a maximum of 1.5 $\mathrm{m}$, the water droplets will gradually shrink and remain in the air. D nature reach someone (radius of 1-1.5 m) and s eseorang with symptoms 
pernafasa an bebicara, shape or sneeze, droplets of water will spread through the nose, mouth or eyes (may be exposed to SARS-CoV-2 Organ virus).

\section{Aerosol}

Aerosols have a term comparable by bioa erosols or water particles small. Aerosols are formed by solid or liquid particles, which expand in the air and are able to stay alive (Wang et al., 2020) Microbial y ang guess ndung in aerosol products capable of spreading throughout the coughing, sneezing, talking, breathing difficulties ( Olsen et

$$
\text { a } 11 ., 2003) \text {. }
$$

Aerosol particles take maximum steps, witha transverse rangeof approximately $1 \mathrm{~m}$. In the aerosol particle ameter, it is usually $0.3-10 \mu$, particles with a size of $1-10 \mu$ can stay in the air for 3 hours, this was done from various other studies (from and odd, 2020). As shown in Table 3.1, the SARS-COV virus can survive at room temperature and on the surface of the substance (KAMPF et al., 2020).

TABLE 3.1 The SARS-CoV virus can survive the following temperatures:

\begin{tabular}{|c|c|c|}
\hline $\begin{array}{c}\text { Type } \\
\text { of Material }\end{array}$ & $\begin{array}{c}\text { Number } \\
\text { of Viruses }\end{array}$ & Time \\
\hline Iron & $10^{5}$ & 5 days \\
\hline Wood & $10^{4}$ & 4 days \\
\hline Paper & $10^{4}-10^{6}$ & $<3$ minutes to 5 days \\
\hline Glass & $10^{5}$ & 4 days \\
\hline Plastic & $10^{5}$ & 4 days \\
\hline $\begin{array}{c}\text { Disposable } \\
\text { dress }\end{array}$ & $10^{4}-10^{6}$ & 1 hour - 2 days \\
\hline
\end{tabular}

The transmission will be lower if the aerosol concentration in the room is relatively closed. Aerosols can be contracted if the person comes in direct contact with the patient. Transmission can occur to patients via

aerosol droplets

\section{Epidemiological Characteristics}

The Case Fatalitiy Rate (CVR) depends on the availability of medical services, the age and health problems of the population, and the number of diagnosed cases. Studies show that by January 2020 , the mortality rate will be between $2 \%$ and $3 \%$. The World Health Organization concludes that in Hubei Province alone, the case fatality rate is around $3 \%$ and $2 \%$ as of February 2020. WHO estimates that the average infection to death ratio (IVR, mortality rate of infected persons) is in the range of $0.8 \%-0.9 \%$.

\section{Clinical Characteristics}

Quoting from the "Guidelines for the

Prevention and Control of Coronav irus Disease " on March $27 \quad 2020$ launched by the Ministry of Health of the Republic of Indonesia that there is a difference with WHO, where in the context of the Ministry of Health of the Republic of Indonesia, based on surveillance that is not an area it is divided into 2 clusters, namely: ODP (person under surveillance) and PDP (patients under surveillance). Meanwhile, WHO shows that the characteristics of people infected with SARS- COV-2 are categorized as 3 groups:

\section{People Without Symptoms (OTG)}

People are confirmed to have the $\mathrm{C}$ orona Virus if they have a history of close contact with someone is a characteristic of the OTG group

2. Group of People Monitoring (ODP)

a. A person who experiences cough, sore throat, runny nose, fever and respiratory problems . In the last 14 days before the onset of symptoms, no one found another cause based on a convincing clinical picture, but reported travel history from country or region

b. People who are characterized by respiratory illness (cough, sore throat, and runny nose) have had direct contact with a confirmed COVID-19 case and have a history of exposure within the past 14 days and before the onset of symptoms.

3. Patient Under Supervision (PDP)

A person with an acute respiratory infection, namely $\quad\left(\geq 38^{\circ} \mathrm{C}\right)$; fever: followed by respiratory symptoms such as: mild to severe pneumonia, runny nose, sore throat, shortness of breath and cough. The CDC report shows that the clinical manifestations of the disease are divided into three parts according to their severity,

namely:

1. Mild : Pneumonia 815 cases

2. B tight : Difficulty breathing, $\mathrm{PaO} 2 / \mathrm{FiO} 2$ ratio [(ratio between oxygen and blood pressure) (partial pressure of oxygen, $\mathrm{PaO} 2$ ), blood oxygen saturation $(\mathrm{SpO} 2)$ $\leq 93 \%$, respiratory rate $\geq 30 / \mathrm{min}$, oxygen supply percentage (oxygen fraction )) FiO2)]] $\leq 300$ and $/$ or pulmonary infiltration> $50 \%$ in 24 to 48 hours, which will occur in $14 \%$ of cases.

3. Serious illness: septic shock, respiratory failure, or multi-organ dysfunction (MOD) or failure (MOF), occurred in 5 cases. 


\section{Dental Procedures Produce Aerosols and Droplets \\ Dental Procedures that Produce Aerosols and} Droplets greatly trigger transmission in dentistry, including :

1. High speed handpiece used in practice

2. Ultrasonic scallers used in practice

3. Three way syringe used in practice

4. Intra oral radiographs

5. Jaw mold

\section{Prevention of Medical Staff and Patients}

Therefore, it is necessary to prevent medical personnel and patients from spreading the corona virus as follows:

\section{Medical personnel}

a. At the beginning of entering the practice room, the medical personnel will change their clothes into clothes that are used for the practice room that has been determined b.Medical personnel use Personal Protective Equipment (PPE) in the prepared room (front hall), and SPO also uses personal protective equipment.

2. The patient is examined

a. When the patient arrives at the clinic, the patient wears a mask and asks him to clean his hands using an alcohol-based hand rub then take anamnesis of symptoms, history and signs of the epdemiology of COVID-19. The results are written on the CPPT. The conclusion is written on the CPPT.

b. Patients are taken to the emergency room if they have signs, symptoms and also a history of the epidemiology of COVID-19

c. A complaint history is carried out if there are no signs, symptoms and epdemiological history of COVID-19

d. When an oral will dperiksa, the first patients are required to wear an apron, melepas mask, then $0.5 \%$ - $1 \%$ hydrogen peroxide is used to rinse in 1 minute duration. Povidone iodine can also be used $(1 \%)$ to rinse your mouth for 15 minutes to 1 minute

e. Before taking action, please obtain patient consent

f. Dental care that requires an aerosol effect is carried out in a special aerosol room

g. He did four handed in dental care.

h. During operation, infection control must be carried out by the operator to avoid sharp objects that can cause injury and any sharp tools to be disposed of must be considered .

i. The action is complete, ask the patient to rinse again then wear a mask and remove the apron he used earlier. j. The medic takes off the outer gloves, gown and wears an alcohol-based hand rub to rinse the gloves .

k. Doctors educate and treat patients

1. Caregiver nurses (executive clinic) disinfect dental tools, equipment.

\section{CONCLUSIONS AND SUGGESTIONS}

\section{Conclusion}

From the literature study conducted, it was found that:

1. COVID-19 caused by SARS-COV2 SARSCOV2 is an RNA virus with a sample (sheath) and is also the $\beta$-COV2 type.

2. The size of the virus particles varies between 60 $140 \mathrm{~nm}$ in diameter.

3. The ability of the virus to enter the host depends on the ability of the virus to bind to ACE2, and the outer membrane receptors expressed on ACE2 epithelial cells.

4. In the dentist's office, the spread COVID-19 occurs by inhaling aerosols or droplets that contain the virus and contact it directly to the fluid in the mouth, mucous membranes, as well as the equipment affected by the virus .

\section{Suggestions}

From the results of a literature study discussing the spread of COVID-19, it is most likely that SARS-COV2 transmission occurs in dental practice:

1. Dentists use PPE level 3 ,

2. Every patient who comes has body temperature checked,

3. Wash your hands in six steps according to World Health Organization regulations ,

4. The waiting room is equipped with disinfectant and the distance between the chairs is 1 meter,

5. Masks must be used

6. Keep your distance .

\section{REFERENCE}

1. ASTM Standards \& COVID-19 (no date). Available at: https://www.astm.org/COVID-19/ (Accessed: 25 June 2020).

2. Ather, A., Patel, Biraj, et al. (2020) 'Coronavirus Disease 19 (COVID-19): Implications for Clinical Dental Care', Journal of Endodontics. Elsevier Inc., pp. 584-595. doi: 10.1016 / j.joen.2020.03.008 
3. Back to Office, Preparing Your Practice (2020). Available at: https://www.cda.org/Portals/0/EasyDNNnews/ Uploads/1927/Preparing your practice -PPE PPE Recommendations for Dental Practices final1.pdf (Accessed: 27 June 2020).

4. Chen, N. et al. (2020) 'Epidemiological and clinical characteristics of 99 cases of 2019 novel coronavirus pneumonia in Wuhan, China: a descriptive study', www.thelancet.com, 395, p. 507.doi: 10.1016 / S01406736 (20) 30211-7

5. Guan, W., Ni, Z., Hu, Y., Liang, W., Ou, C., He, J.,... Zhong, N. (2020). Clinical Characteristics of Coronavirus Disease 2019 in China. The New England Journal of Medicine, $382 \quad$ (18), 17081720. https://doi.org/10.1056/NEJMoa2 002032

6. Handayani, D., Hadi, DR, Isbaniah, F., Burhan, E., \& Agustin, H. (2020). 2019 Corona Virus Disease. Indonesian Journal of Respirology, 40 (2), 119-129.

7. Harrel, SK and Molinari, J. 'Aerosols and splatter in dentistry', Journal of the American Dental Association (1939), 135 (4), pp. 429437.doi: 10.14219 jada.archive.2004.0207

8. Kampf, G. et al. 'Persistence of coronaviruses on inanimate surfaces and their inactivation with biocidal agents', Journal of Hospital Infection, 104 (3), pp. 246251.doi: 10.1016 / j. jhin.2020.01.022.K.Tsia, K.Lee and Q.Lai (no date) Oral Diseases, Wiley OnlineLibrary.doi: 10.1111 / (ISSN) 1601-0825.

9. Ministry of Health of the Republic of Indonesia (2020) Ministry of Health of the Republic of Indonesia. Available

https://www.kemkes.go.id/article/view/2003

1900002 / Dashboard-Data-Cases-COVID19di-Indonesia.html (Accessed: 6 July 2020).

10. Laheij, AMGA et al. (2012) 'Healthcareassociated viral and bacterial infections in dentistry', Journal of Oral Microbiology, 4, pp. $1-10$.

11. Lai, ENT et al. (2020) 'Stepping up infection control measures in ophthalmology during the novel coronavirus outbreak: an experience from Hong Kong', Graefe's Archive for Clinical and Experimental Ophthalmology. Graefe's Archive for Clinical and Experimental Ophthalmology, 258 (5), pp. 1049-1055. doi: 10.1007 / s00417020-04641-8.

12. Li, H. et al. 'Coronavirus disease COVID-19): current status and future perspectives', International Journal of Antimicrobial Agents, 55 (5), p. 105951 . doi: 10.1016 /

h. ijantimicag.2020.105951.

13. Meng, L., Hua, F. and Bian, Z. (2020) 'Coronavirus Disease 2019 (COVID-19): Emerging and Future Challenges for Dental and Oral Medicine', Journal of Dental Research, 99
(5), pp. 481-487. doi: 10.1177 / 0022034520914246

14. Olsen, SJ et al. (20 'Transmission of the Severe Acute Respiratory Syndrome on Aircraft', New England Journal of Medicine. Massachusetts Medical Society, 349 (25), pp. 24162422.doi: 10.1056 / NEJMoa031349.

15. Peng, X. et al. (2020) 'Transmission routes of $2019 \mathrm{nCoV}$ and controls in dental practice', International Journal of Oral Science. Springer Nature, pp. 1-6. doi: 10.1038 / s41368-0200075-9.

16. Wang, J. and Du, G. 'COVID-19 may transmit through aerosols', Irish Journal of Medical Science (1971 -). doi: 10.1007 / s11845-02002218-2.

17. World Health Organization, Pandemic and Epidemic Diseases and World Health Organization (2014) Infection prevention and control of epidemic- and pandemic-prone acute respiratory infections in health care: WHO guidelines. Available at: http://apps.who.int/iris/bitstre am / 10665/112656/1 / 9789241507134_eng.pdf? Ua $=1$ (Accessed: 29 June 2020).

18. Zhu, N., Zhang, D., Wang, W. , Li, X., Yang, B., Song, J., Tan, W. (2020). A Novel Coronavirus from Patients with Pneumonia in China, 2019. The New England Journal of Medicine, 382 (8), 727 733. https://doi.org/10.1056/NEJMoa2 001017 